\title{
Computers \\ in Critical Care and \\ Pulmonary Medicine
}

Edited by P. M. Osswald

in Cooperation with

O. Prakash, H.-J. Hartung and H. J. Bender

With 197 Figures and 29 Tables

Springer-Verlag

Berlin Heidelberg New York Tokyo 


\section{Table of Contents}

Application of Computer Systems in Critical Care

K. Geiger . . . . . . . . . . . . . . . . . . . . . . . . . 1

On-line Cardiovascular Applications of Microcomputers in Intensive Care

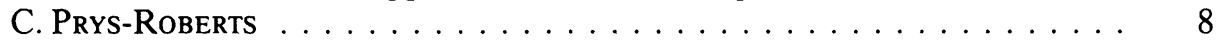

Organizing and Analyzing Clinical Information Using Table-Based, Graphics-Oriented, Interactive Computer Systems

B. J. RansIL . . . . . . . . . . . . . . . . . . . . . . . . . . 17

An Attempt to Solve the "Information Explosion" in an Intensive Care Ward D. J. Price, J. MASON, and S. SNOWden . . . . . . . . . . . . . . . 23

Towards a Coherent Structure of the Anesthetist - Computer Interface

S. Trispel, H. Klocke, G. Rau, and R. Schlimgen . . . . . . . . . . . . . . . 29

Effect of Different Ventilation Patterns on the Intracranial Pressure

in Neurologic Patients with Mechanical Ventilation

K. M. Einhäupl, C. Garner, G. Schmieder, G. Kerscher, and R. WieczoreK

Computer Applications in Pulmonary Function Testing

M. HeITZ

The Assessment of Gas Exchange by Automated Analysis

of $\mathrm{O}_{2}$ and $\mathrm{CO}_{2}$ Alveolar to Arterial Differences:

3 Years Experience in Respiratory Clinical Physiology

P. Paoletti, E. Fornai, A. G. Neto, R. Prediletto, S. Ruschi, and C. Giuntini

Computers in Experimental Pathophysiological Research

R. Schosser, H.-P. Engel, and K. Messmer . . . . . . . . . . . . . . 66

Data Bases in Acute Medicine

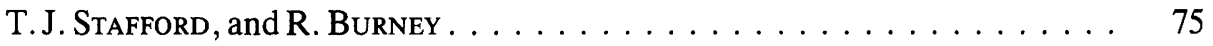

Computerized Clinical Records in the Neurosurgical ICU

with Self-updating of Some Biological Data

R. Urciuoli, M. Knaflitz, G. Balestra, M. A. Arbinolo, M. L. Bellero,

R. Bertino, C. Franco, M. Gessa, and A. Guarnaccia . . . . . . . . . . . . 
Organization and Analysis of Data from Patients with Trauma and Hemorrhage

W. Kellermann, K. Peter, U. Jensen, Y. Summa, and D. Neumeier . . . . . .

Computer Assisted ICU Monitoring

T. Oyama, H. Ishihara, A. Matsuki, M. Yamashita, K. Isozaki, and T. Suzuki 96

Automatic Signal Analysis and Prediction in Intensive Medical Care

A. Swoboda , and E. EPPLE . . . . . . . . . . . . . . . . . . . . 100

Artifact Processing in a Computerized Intensive Care Unit

W. Bleicher, E. EPPle, M. Kopp, and H. Junger . . . . . . . . . . . . . . . 107

Personal Computers for Gas Exchange Measurements in the ICU

G. Wiesspeiner, S. Schuy, H. Metzler, and W. List . . . . . . . . . . . 116

Integration of a New Computer HP 9816S in the Pulmonary Calculator

System HP 47804S. Advantages of Using the Screen for Graphic Presentation of Flow-Volume Curves

K. ERdMAnN, and J.-P. JANTZEN . . . . . . . . . . . . . . . . . . . . 123

Measurement of Oxygen Uptake with a New Method

H. MetZler, G. WiesSPEINER, and W.F. List . . . . . . . . . . . . . 130

A Microcomputerassisted System for the Monitoring

of Cardiorespiratory Variables in the Critically Ill

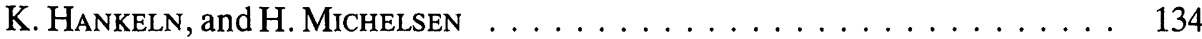

Selective Lung Ventilation

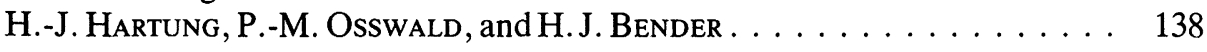

Automated Anesthetic Record Keeping

N. Ty Sмith . . . . . . . . . . . . . . . . . . . . . . . .

Computer Aided Methods to Predict Perioperative Risks

U. Feldmann, P.-M. Osswald, H.-J. Hartung, and H. Lutz . . . . . . . . . 162

New Tasks for Medical Informatics?

C. O. KÖHLER . . . . . . . . . . . . . . . . . . . . . . . . . . . . . . . . . 184

Artificial Intelligence: the Expert Systems Approach to Medical Consultation

E. H. ShortLiffe, and L. M. FAgAN . . . . . . . . . . . . . . . . . . . 190

Expert Consultation Systems in Medicine

P.L. Miller . . . . . . . . . . . . . . . . . . . . . . . . . . . . . . . . 198

The Importance of Using a Computer to Provide Pediatric Anesthesia and

Emergency Drug Information and Treatment Regimens in the Clinical Setting

D. J. Essin, D. L. WARner, M. Jagodowicz, and S. N. Steen . . . . . . . . . . 207

Computer Systems in Artificial Ventilations (New Techniques)

W. Koller, A. Aloy, N. Mutz, and G. Pauser . . . . . . . . . . . . 
Series Dead Space Volume Assessed as the Mean Value of a Distribution Function

G. Wolff, and J. X. Brunner . . . . . . . . . . . . . . . . . . . 221

Evaluation of Indices for Respiratory Mechanics from an Automated System

B. Friberg, M. Forssblad, S. Baehrendtz, J. Hulting, K. Ekenbäck,

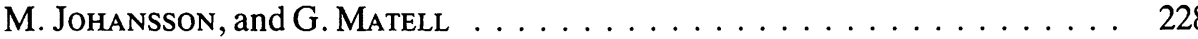

Mathematical Modelling for Prediction of Optimal Ventilator Settings

R. Rudowski, G. Matell, K. Ekenbäck, C. Spanne, and B. Ossmer . . . . . 235

Indications for the Application of Closed Loop Systems

in Perioperative Medicine

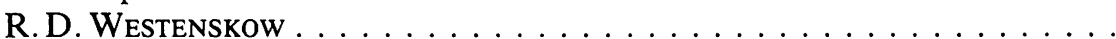

Glucose-Insulin-Potassium Therapy Guided by a Glucose-Controlled Insulin Infusion System in Acute Myocardial Infarction

G. Müller-Esch, P. Ball, U. Bekemeyer, H. Djonlagic, A. Hauptmann,

K. Heidbüchel, A. Peters, R. Tybussek, W. G. Wood, and P. C. Scriba . . . .

Changes in Monitoring Methods Caused by the Use

of Intelligent Bedside Equipment

E. Epple, W. Bleicher, M. Kopp, and H. Junger . . . . . . . . . . . . . . . . 259

Automated Arrhythmia Detection in Intensive Care

C. Zeelenberg, S. H. Meij, M. R. Hoare, and P. G. Hugenholtz . . . . . .

Monitoring Intracranial Pressure - Nuisance to, or Advantages for,

Ward Personnel

K. Wiedemann, G. Schmidt, and M. Müller . . . . . . . . . . . . . . . 280

Computerized Neuromonitoring

M.R. GAAB . . . . . . . . . . . . . . . . . . . . . . . . . . . 290

Computer-Assisted Monitoring of Intracranial Pressure in Stroke

A. HAAss, T. MAdLER, and K. SchimrigK . . . . . . . . . . . . . . 307

Microprocessor-Controlled Registration and Evaluation

of Respiratory Pressure-Volume Diagrams in ICUs

W. Kellermann, Y. Summa, and K. Peter . . . . . . . . . . . . . . . 311

NAPROS - A semiautomatic and easy to use anaesthetic record system

D. Winter, and P.-M. Osswald . . . . . . . . . . . . . . . . . . . . . . . 319

A Real Time Pattern Recognition Program

for Continuous Processing of Cardiovascular Biosignals

M. Marwald . . . . . . . . . . . . . . . . . . . . . . . . . . 329

Microcomputer-Assisted ICP Monitoring in Neurological Patients

G. Schmieder, C. Garner, K. M. EinhÄUPL, K. Siegl, and G. Kufner . . . . . 334 


\title{
Glucose-Insulin-Potassium Therapy Guided by a Glucose-Controlled Insulin Infusion System in Acute Myocardial Infarction
}

\author{
G. Müller-Esch, P. Ball, U. Bekemeyer, H. Djonlagic, A. Hauptmann,
} K. Heidbüchel, A. Peters, R. Tybussek, W. G. Wood, and P. C. Scriba

A number of hormonal and metabolic alterations have been observed during acute myocardial infarction (AMI): There is a rapid increase of catecholamine and cortisol secretion; free fatty acid (FFA) serum levels are markedly elevated (Gupta et al. 1969; Januszewicz et al. 1971; Vetter et al. 1974); and insulin secretion may be inappropiately low. These alterations result in a disturbance of glucose utilization, socalled stress hyperglycemia. Moreover, under these conditions and due to the accumulation of free fatty acids in the ischemic myocardium, severe ventricular arrhythmias as well as a progression of myocardial cell damage are likely to occur (Kurien and Oliver 1970; Kurien et al. 1971; Oliver et al. 1968).

Glucose-insulin-potassium infusions (GIK) in AMI have been used in a number of clinical trials in order to overcome these deleterious effects (Mantle et al. 1981; Rogers et al. 1976, 1979; Sodi-Palleres et al. (1962)). Some of the postulated benefits of GIK treatment in AMI are: a decrease of FFA, a reduction of potassium efflux, a repletion of intracellular potassium stores, an enhancement of myocardial glucose utilization, a reduction of myocardial oxygen consumption, and an improvement in coronary perfusion. These changes should reduce severe life-threatening arrhythmias, limit infarct size, improve left ventricular function, and reduce hospital mortality (von Arnim and Bolte 1980; Brachfeld 1973; Kurien et al. 1971; Manke et al. 1981; Oliver 1973). With an "open loop" fixed GIK regime as in the studies mentioned above, severe hyperglycemia as well as hypoglycemia were not infrequently seen, because the degree of impairment of the insulin sensitivity could not be predicted. We therefore decided to use a glucose - controlled insulin infusion system (GCIIS); this involves applying "closed-loop" control during treatment with GIK according to the individual insulin sensitivity and thereby studying hormonal and metabolic patterns in AMI.

\section{Methods}

Nine patients (eight male, one female; age $61.8 \pm 8.8$ years) with AMI admitted to our intensive care unit within $12 \mathrm{~h}$ after onset of chest pain received GIK for $24 \mathrm{~h}$. The solution contained $430 \mathrm{~g}$ glucose, $166 \mathrm{U}$ porcine regular insulin, and $133 \mathrm{mEq} \mathrm{KCl} \mathrm{per}$ liter. The infusion rate was $0.9 \mathrm{ml} / \mathrm{kg} / \mathrm{h}$. Additional feedback - controlled insulin and/ or glucose was given by the GCIIS (Biostator-Controller). The following constants were chosen: Mode 3:1, Var 100, BI 80, BD 60, and FI 500-1000. Insulin concentra- 
Fig. 1. Schematic diagram of device used for processing of GCIIS data

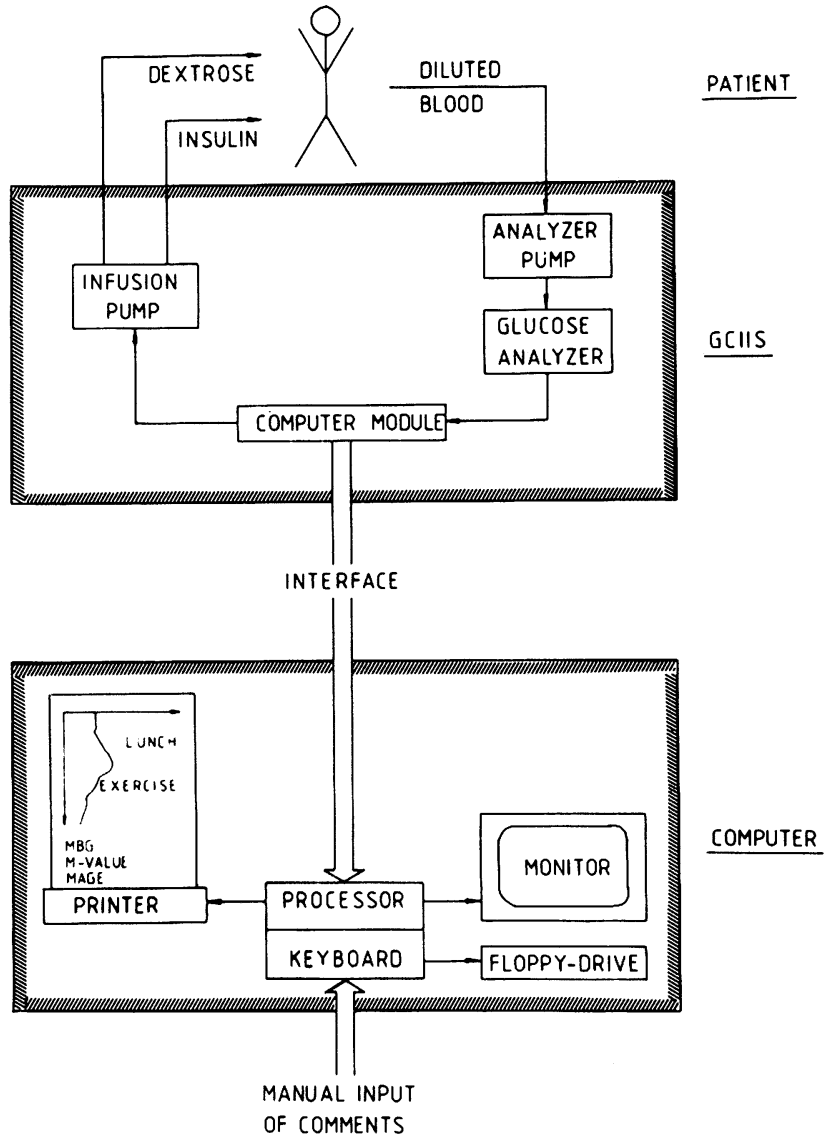

tion of the GIK solution was increased when blood glucose could not be kept below $250 \mathrm{mg} / \mathrm{dl}$. Insulin, C-peptide, cortisol, GH, prolactin, and lactate were determined at 6-h intervals. FFAs were measured by gas-liquid chromatography (Tserng et al. 1981). Figure 1 shows a schematic diagram of the technical equipment. The patient is connected to the GCIIS. By means of an interface all data for blood glucose (BG), insulin infusion rate (IR), and dextrose infusion rate (DR) are transferred directly from the Biostator to a microcomputer for further processing (Muller-Esch et al. 1984). The microcomputer fulfils several functions:

1. Monitoring: BG, IR, and DR are plotted continuously

2. Manual input: comments concerning, for example, the actual therapy can be entered via the keyboard

3. Calculations: a BASIC computer program has been developed for the calculation of the glycemic indices mean blood glucose (MBG), M-value, and MAGE (Muller-Esch et al. 1984)

4. Printer and floppy disks: all values for BG, IR, and DR, as well as comments which appear in their time - related positions, and calculated parameters are plotted and documented on 5-in. floppy disks. 


\section{Results}

The insulin sensitivity - as measured by blood glucose concentrations and total insulin requirements during GIK - varied markedly. Figure $2 \mathrm{a}$ is an example from a patient with high insulin requirements. Initial BG is about $110 \mathrm{mg} / \mathrm{dl}$, rising to more than 250 $\mathrm{mg} / \mathrm{dl}$ after starting GIK infusion. Despite submaximal additional feedback-controlled insulin by the GCIIS, BG did not fall below $200 \mathrm{mg} / \mathrm{dl}$. In contrast, in the patient shown in Fig. 2b, euglycemia during GIK could be obtained with only minor additional feedback-controlled insulin administration. And in another patient, additional feedback-controlled dextrose had to be given to prevent hypoglycemia during GIK, MBG being in the range of about $80 \mathrm{mg} / \mathrm{dl}$ (Fig. $2 \mathrm{c}$ ).

According to these data we can divide our patients into two groups: in five patients (group A), a total of $309 \pm 52 \mathrm{U}$ insulin/24 h was sufficient to maintain fair glycemic control (Table 1, top). In four patients, however (group B), insulin concentration of GIK had to be partially multiplied because of marked hyperglycemia: insulin requirements were $1193 \pm 258 \mathrm{U} / 24 \mathrm{~h}$; despite this, we did not achieve nearly normal BG values or nearly normal glycemic indices (Table 1 , bottom).

When compared to the "low insulin" group, the "high insulin" group presented with higher serum insulin levels before GIK treatment. During therapy, this group had higher values for $\mathrm{C}$-peptide, cortisol, prolactin, and lactate. $\mathrm{GH}$ and glucagon did not differ significantly (Table 1).

Table 1. Insulin, C-peptide, glucagon, cortisol, GH, prolactin, and lactate serum levels during GCIIS-guided GIK therapy in patients with low insulin requirements (group A) and high insulin requirements (group B). The glycemic indices MBG, MAGE, and M-value are also shown. $(P<0.05$ vs. group A)

\begin{tabular}{|c|c|c|c|c|c|}
\hline \multicolumn{6}{|c|}{ Group A $(309 \pm 52 U$ insulin/24 $h, n=5)$} \\
\hline & $0 \mathrm{~h}$ & $6 \mathrm{~h}$ & $12 \mathrm{~h}$ & $18 \mathrm{~h}$ & $24 \mathrm{~h}$ \\
\hline Insulin (mU/l) & & & & & \\
\hline C-peptide $(\mu \mathrm{g} / \mathrm{l})$ & $2.6 \pm 1.8$ & $1.0 \pm 0.7$ & $0.6 \pm 0.5$ & $2.5 \pm 4.1$ & $2.1 \pm 2.5$ \\
\hline Glucagon (ng/l) & $140 \pm 25$ & $158 \pm 53$ & $160 \pm 84$ & $176 \pm 82$ & $164 \pm 74$ \\
\hline Cortisol (ng/ml) & $233 \pm 131$ & $172 \pm 98$ & $196 \pm 95$ & $212 \pm 112$ & $188 \pm 92$ \\
\hline $\mathrm{GH}(\mathrm{ng} / \mathrm{ml})$ & $2.1 \pm 1.5$ & $4.4 \pm 2.9$ & $4.2 \pm 2.0$ & $3.5 \pm 2.5$ & $2.1 \pm 1.6$ \\
\hline Prolactin $(\mu \mathrm{U} / \mathrm{ml})$ & $398 \pm 131$ & $258 \pm 64$ & $242 \pm 72$ & $225 \pm 79$ & $248 \pm 51$ \\
\hline Lactate $(\mathrm{mmol} / \mathrm{l})$ & $1.4 \pm 0.5$ & $2.0 \pm 1.0$ & $1.6 \pm 0.8$ & $1.3 \pm 0.6$ & $1.1 \pm 0.3$ \\
\hline MBG: $94 \pm 28$ & \multicolumn{3}{|c|}{ MAGE: $51 \pm 8$} & \multicolumn{2}{|c|}{ M-value: $17 \pm 7$} \\
\hline
\end{tabular}

Group B $(1193 \pm 258$ U insulin/24 $h, n=4)$

$\begin{array}{lccccc} & 0 \mathrm{~h} & 6 \mathrm{~h} & 12 \mathrm{~h} & 18 \mathrm{~h} & 24 \mathrm{~h} \\ \text { Insulin }(\mathrm{mU} / \mathrm{l}) & \bullet 43 \pm 22 & \bullet>500 & \bullet>500 & \bullet>500 & \bullet>500 \\ \text { C-peptide }(\mu \mathrm{g} / \mathrm{l}) & 8.0 \pm 7.5 & \bullet 13.4 \pm 12.9 & \bullet 5.0 \pm 14.3 & 21.6 \pm 22.9 & 12.3 \pm 15.6 \\ \text { Glucagon }(\mathrm{ng} / \mathrm{l}) & 152 \pm 77 & 87 \pm 62 & 90 \pm 73 & 124 \pm 140 & 15.1 \pm 169 \\ \text { Cortisol }(\mathrm{ng} / \mathrm{ml}) & 301 \pm 224 & \bullet 418 \pm 135 & \bullet 418 \pm 174 & \bullet 412 \pm 203 & \bullet 418 \pm 186 \\ \mathrm{GH}(\mathrm{ng} / \mathrm{ml}) & 3.1 \pm 2.4 & 6.1 \pm 2.4 & 3.0 \pm 1.8 & 1.7 \pm 1.4 & 1.5 \pm 1.2 \\ \text { Prolactin }(\mu \mathrm{U} / \mathrm{ml}) & 590 \pm 281 & \bullet 549 \pm 182 & \bullet 489 \pm 150 & \bullet 532 \pm 135 & \bullet 681 \pm 191 \\ \text { Lactate }(\mathrm{mmol} / \mathrm{l}) & \bullet 2.7 \pm 1.3 & \bullet 3.5 \pm 0.8 & 2.7 \pm 0.9 & \bullet 2.7 \pm 1.2 & \bullet 3.5 \pm 1.4\end{array}$




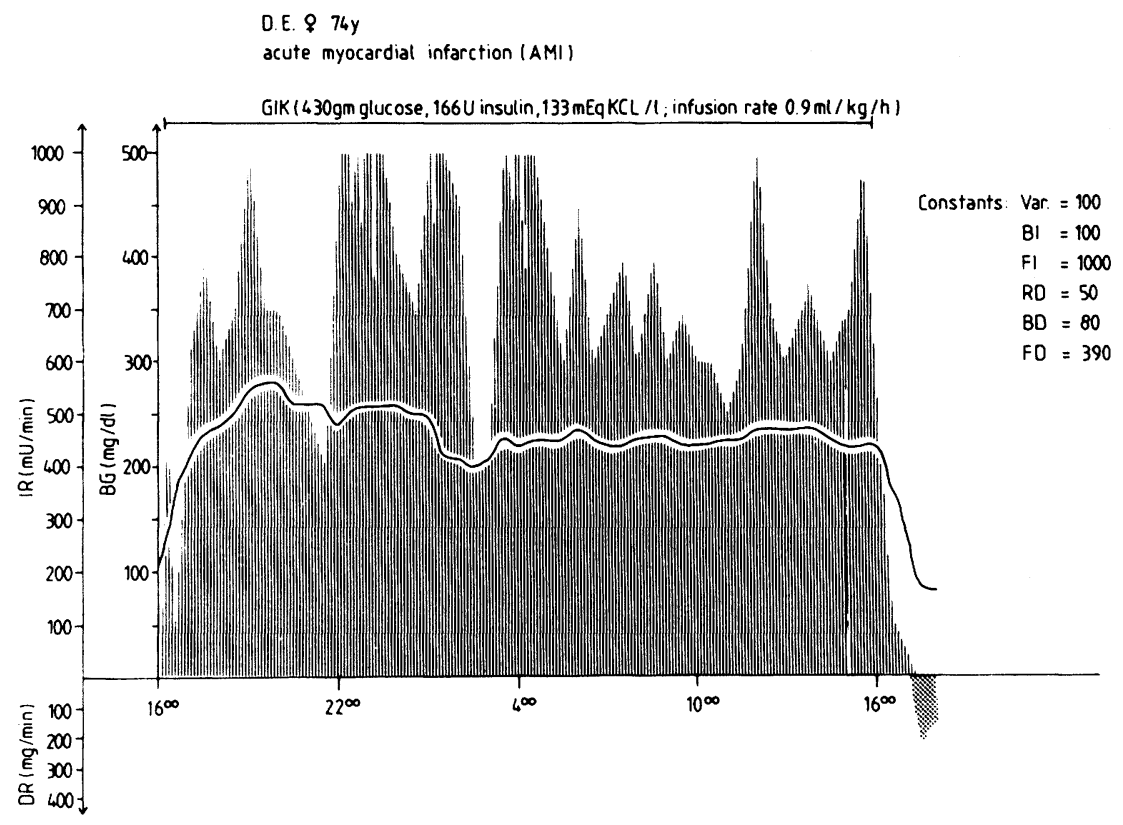

Fig. 2a

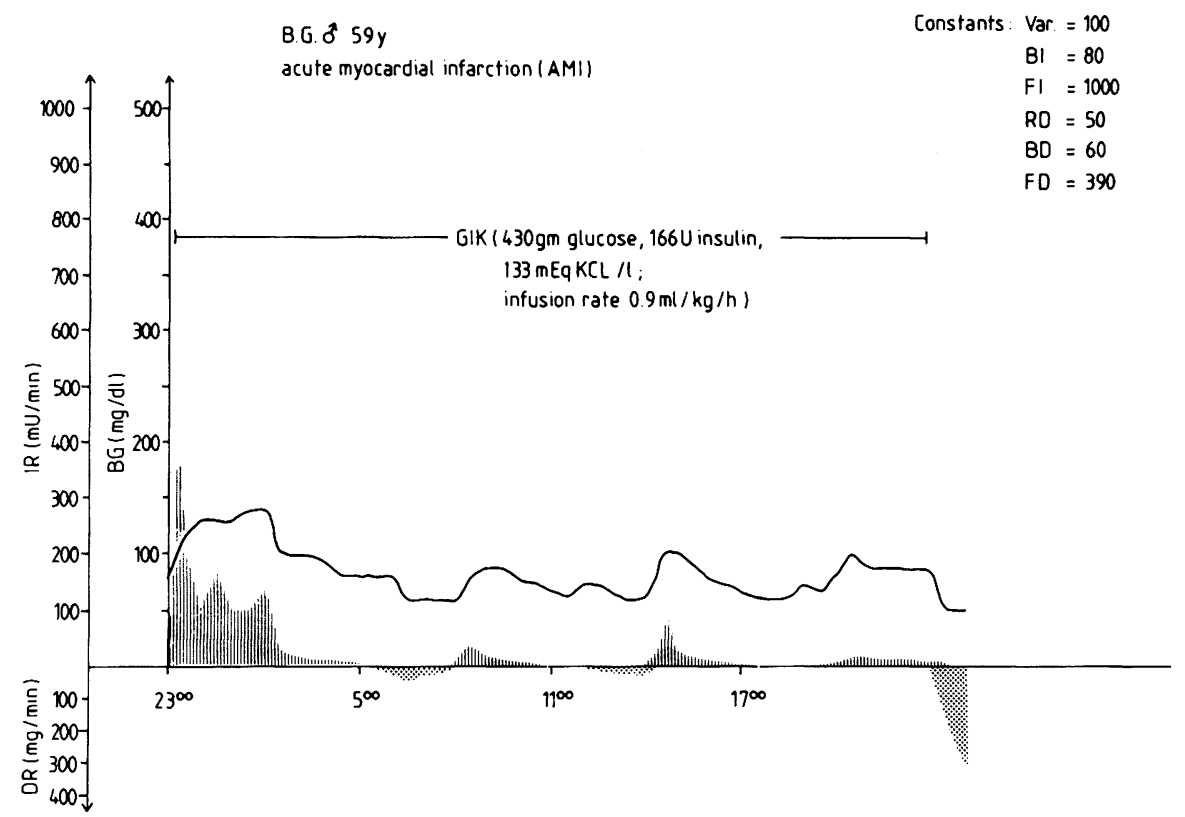

Fig. 2b

Fig. 2a-c. Blood glucose (BG), insulin infusion rate (IR), and dextrose infusion rate (DR) during GCIIS-guided GIK therapy in three patients with AMI 


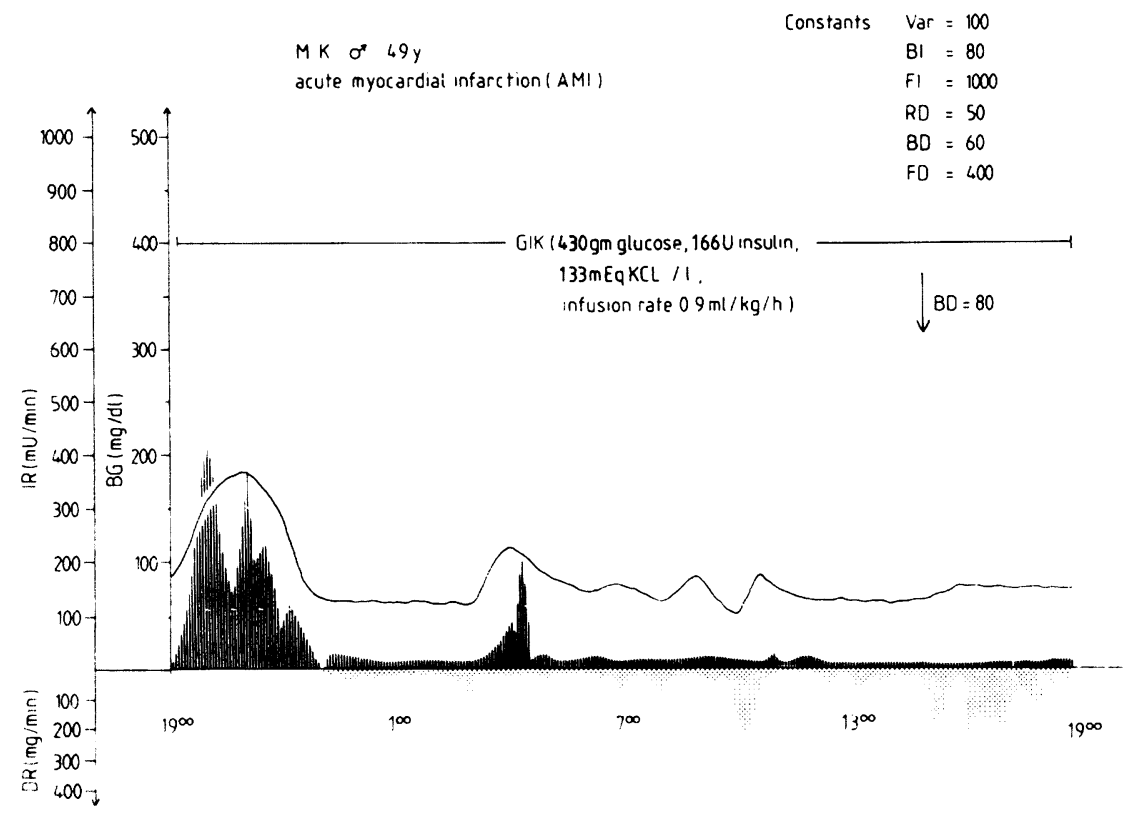

Fig. 2c

Table 2. Insulin, C-peptide, glucagon, cortisol, GH, prolactin, lactate, and blood glucose (BG) levels in seven conventionally treated patients with AMI as compared to four patients under GCIISguided GIK therapy (group B). $\bullet P<0.05$ vs. controls)

\begin{tabular}{lccccc}
\hline Controls $(n=7)$ & \multicolumn{5}{c}{} \\
& $0 \mathrm{~h}$ & $6 \mathrm{~h}$ & $12 \mathrm{~h}$ & $18 \mathrm{~h}$ & $24 \mathrm{~h}$ \\
Insulin $(\mathrm{mU} / \mathrm{l})$ & $35 \pm 17$ & $18 \pm 11$ & $26 \pm 24$ & $26 \pm 24$ & $39 \pm 34$ \\
C-peptide $(\mu \mathrm{g} / \mathrm{l})$ & $5.4 \pm 2.9$ & $4.9 \pm 3.3$ & $4.7 \pm 3.2$ & $6.4 \pm 3.3$ & $8.6 \pm 6.2$ \\
Glucagon $(\mathrm{ng} / \mathrm{l})$ & $323 \pm 446$ & $373 \pm 537$ & $348 \pm 412$ & $431 \pm 497$ & $443 \pm 407$ \\
Cortisol $(\mathrm{ng} / \mathrm{ml})$ & $239 \pm 145$ & $266 \pm 192$ & $218 \pm 108$ & $247 \pm 171$ & $229 \pm 163$ \\
$\mathrm{GH}(\mathrm{ng} / \mathrm{ml})$ & $2.1 \pm 3.1$ & $2.9 \pm 3.8$ & $2.4 \pm 2.7$ & $3.3 \pm 6.5$ & $2.6 \pm 2.6$ \\
Prolactin $(\mu \mathrm{U} / \mathrm{ml})$ & $834 \pm 895$ & $445 \pm 256$ & $273 \pm 106$ & $228 \pm 50$ & $306 \pm 74$ \\
Lactate $(\mathrm{mmol} / \mathrm{l})$ & $2.1 \pm 2.1$ & $2.1 \pm 1.8$ & $1.7 \pm 1.1$ & $1.4 \pm 0.5$ & $1.4 \pm 0.4$ \\
BG $(\mathrm{mg} / \mathrm{dl})$ & $147 \pm 38$ & $157 \pm 49$ & $122 \pm 23$ & $144 \pm 48$ & $162 \pm 72$ \\
\hline
\end{tabular}

Group B $(1193 \pm 258 U$ insulin $/ 24 h, n=4)$

$\begin{array}{lccccc} & 0 \mathrm{~h} & 6 \mathrm{~h} & 12 \mathrm{~h} & 18 \mathrm{~h} & 24 \mathrm{~h} \\ \text { Insulin }(\mathrm{mU} / \mathrm{l}) & 43 \pm 22 & >500 & >500 & >500 & >500 \\ \text { C-peptide }(\mu \mathrm{g} / \mathrm{l}) & 8.0 \pm 7.5 & 13.4 \pm 12.9 & -15.0 \pm 14.3 & 21.6 \pm 22.9 & 12.3 \pm 15.6 \\ \text { Glucagon }(\mathrm{ng} / \mathrm{l}) & 152 \pm 77 & 87 \pm 62 & 90 \pm 73 & 124 \pm 140 & 151 \pm 169 \\ \text { Cortisol }(\mathrm{ng} / \mathrm{ml}) & 301 \pm 224 & 418 \pm 135 & -418 \pm 174 & 412 \pm 203 & 418 \pm 186 \\ \mathrm{GH}(\mathrm{ng} / \mathrm{ml}) & 3.1 \pm 2.4 & 6.1 \pm 2.4 & 3.0 \pm 1.8 & 1.7 \pm 1.4 & 1.5 \pm 1.2 \\ \text { Prolactin }(\mu \mathrm{H} / \mathrm{ml}) & 590 \pm 281 & 549 \pm 182 & \bullet 489 \pm 150 & \bullet 532 \pm 135 & 681 \pm 191 \\ \text { Lactate }(\mathrm{mmol} / \mathrm{l}) & 2.7 \pm 1.3 & 3.5 \pm 0.8 & 2.7 \pm 0.9 & \bullet 2.7 \pm 1.2 & \bullet 3.5 \pm 1.4\end{array}$

MBG: $234 \pm 42$ 
Fig. 3. Free fatty acids (FFA) during GCIIS-guided GIK therapy in two patients with AMI

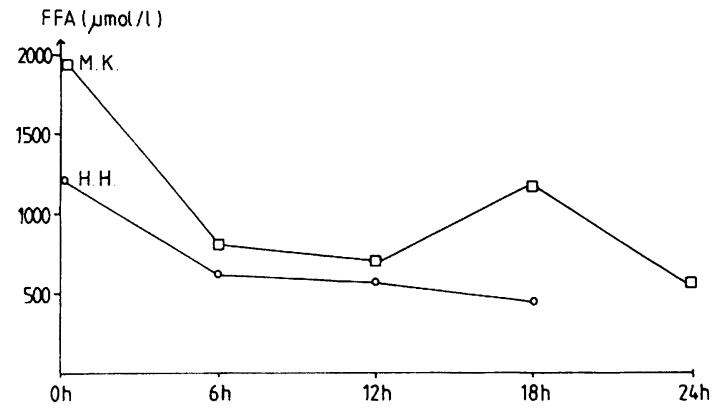

Seven conventionally, treated patients with AMI served as controls (Table 2). In comparison with these patients without GIK, group B had higher serum levels for C-peptide, cortisol, prolactin, and lactate.

Serial FFA measurements in two patients show a decrease of FFA under GIK below the arrhythmia threshold (Oliver et al. 1968) of $1200 \mu \mathrm{mol} / \mathrm{l}$ (Fig. 3).

\section{Discussion}

Because of the small number of patients we are not yet able to decide whether the observed hormonal-metabolic differences between the groups are directly correlated to the infarct size or wheter they reflect different systemic reactions, different hormonal-metabolic patterns, during AMI.

In conclusion, these preliminary data indicate that the impairment of insulin sensitivity and glucose utilization during AMI varies markedly. FFA can be reduced below the arrhythmia threshold. Further studies should compare metabolic, hemodynamic, and antiarrhythmogenic effects of GCIIS-guided GIK support in patients with AMI.

\section{References}

Von Arnim T, Bolte HD (1980) Therapie mit Glukose-Insulin beim kardiogenen Schocksyndrom. In: Brückner JB (ed) Kreislaufschock. Springer, Berlin Heidelberg New York, pp 500-505

Brachfeld N (1973) The glucose-insulin-potassium (GIK) regimen in the treatment of myocardial ischemia. Circulation 47: 459-462

Gupta DK, Jewitt DE, Young R, Hartog M, Opie LM (1969) Increased plasma-free-fatty-acid concentrations and their significance in patients with acute myocardial infarction. Lancet 2: $1209-1213$

Januszewicz W, Sznajdermann M, Ciświcka-Sznajdermann M, Wocial B, Rymaszewski Z (1971) Plasma free fatty acid and catecholamine levels in patients with acute myocardial infarction. $\mathrm{Br}$ Heart J 33: 716-718

Kurien VA, Oliver MF (1970) A metabolic cause for arrhythmias during acute myocardial hypoxia. Lancet 1: 813-815

Kurien VA, Yates PA, Oliver MF (1971) The role of free fatty acids in the production of ventricular arrhythmias after acute coronary artery occlusion. Eur J Clin Invest 1: 225-241 
Mantle JA, Rogers WJ, Smith LR, McDaniel HG, Papapietro JE, Russell RO, Rackley CH (1981) Clinical effects of glucose-insulin-potassium on left ventricular function in acute myocardial infarction: results from a randomized clinical trial. Am Heart J 102: 313-324

Müller-Esch G, Peters A, Göhl M, Heidbüchel K, Scriba PC (1984) Simplified evaluation and documentation of data from glucose controlled insulin infusion systems (GCIIS). Biomed Technik 29: $62-66$

Oliver MF (1973) Glucose, insulin, potassium in acute myocardial infarction. Acta Cardiol [Suppl] 17: 257-262

Oliver MF, Kurien VA, Greenwood TW (1968) Relation between serum-free-fatty acids and arrhythmias and death after acute myocardial infarction. Lancet 1: 710-715

Rogers WJ, Stanley AW, Breinig JB, Prather JW, McDaniel MG, Moraski RE, Mantle JA, Russell RO Jr, Rackley CE (1976) Reduction of hospital mortality rate of acute myocardial infarction with glucose-insulin-potassium infusion. Am Heart J 92: 441-454

Rogers WJ, Segall PH, McDaniel HG, Mantle JA, Russell RO Jr, Rackley CE (1979) Prospective randomized trial of glucose-insulin-potassium in acute myocardial infarction. Effects on myocardial hemodynamics, substrates and rhythm. Am J Cardiol 43: 801-809

Sodi-Pallares D, Testelli MK, Fishleder BL, Bisteni A, Medrano GA, Friedland C, DeMicheli A (1962) Effects of an intravenous infusion of a potassium-glucose-insulin solution on the electrocardiographic signs of myocardial infarction. Am J Cardiol 9: 166-181

Tserng KY, Kliegmann RM, Miettinen EL, Kalhan SC (1981) A rapid, simple, and sensitive procedure for the determination of free fatty acids in plasma using glass capillary columm gas-liquid chromatography. J Lipid Res 22: 852-858

Vetter NJ, Strange RC, Adams W, Oliver NF (1974) Initial metabolic and hormonal response to acute myocardial infarction. Lancet 1: 284-289 